
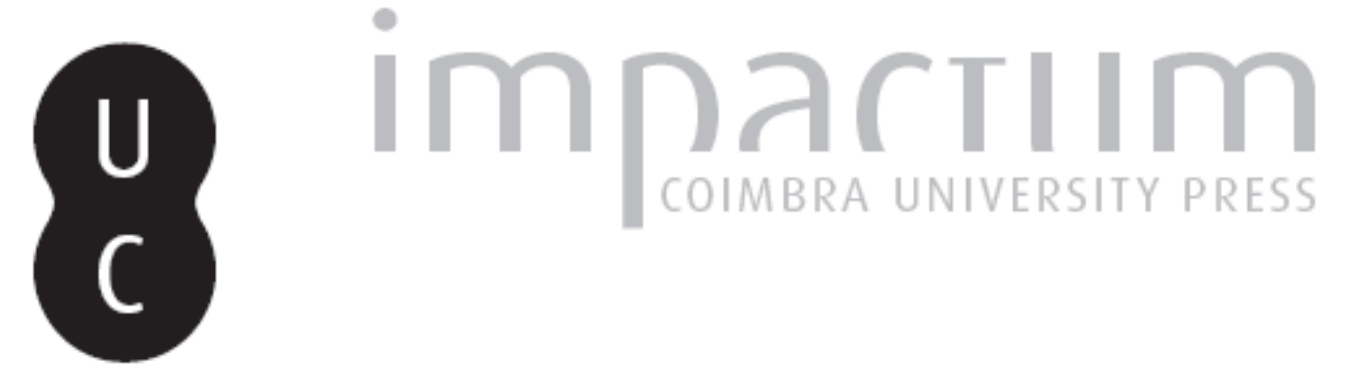

\title{
Atlântico e Mediterrâneo nos portos romanos do Sado
}

\section{Autor(es): Mantas, Vasco Gil}

Publicado por: Instituto de História Económica e Social, Faculdade de Letras da Puniversidade de Coimbra

URL persistente:

URI:http://hdl.handle.net/10316.2/9708

DOI:

DOI:http://dx.doi.org/10.14195/0870-4147_41_8

Accessed : $\quad$ 26-Apr-2023 14:06:37

A navegação consulta e descarregamento dos títulos inseridos nas Bibliotecas Digitais UC Digitalis, UC Pombalina e UC Impactum, pressupõem a aceitação plena e sem reservas dos Termos e Condições de Uso destas Bibliotecas Digitais, disponíveis em https://digitalis.uc.pt/pt-pt/termos.

Conforme exposto nos referidos Termos e Condições de Uso, o descarregamento de títulos de acesso restrito requer uma licença válida de autorização devendo o utilizador aceder ao(s) documento(s) a partir de um endereço de IP da instituição detentora da supramencionada licença.

Ao utilizador é apenas permitido o descarregamento para uso pessoal, pelo que o emprego do(s) título(s) descarregado(s) para outro fim, designadamente comercial, carece de autorização do respetivo autor ou editor da obra.

Na medida em que todas as obras da UC Digitalis se encontram protegidas pelo Código do Direito de Autor e Direitos Conexos e demais legislação aplicável, toda a cópia, parcial ou total, deste documento, nos casos em que é legalmente admitida, deverá conter ou fazer-se acompanhar por este aviso.

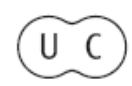





\title{
Atlântico e Mediterrâneo nos portos romanos do Sado*
}

\author{
Vasco Gil Mantas \\ Universidade de Coimbra \\ vgmantas@yahoo.com
}

\section{Resumo:}

Os principais portos do Sado na época romana, Salacia, Caetobriga e Tróia, permitem abordar, pela sua privilegiada situação na fachada ocidental da Hispânia, o tema sempre debatido da romanização. O estudo destes centros portuários, todos de diferente estatuto, embora servindo as actividades económicas características da região, mostra como se combinaram, ao longo de dezoito ou vinte gerações, factores típicos do mundo atlântico com as novidades e as dinâmicas de origem mediterrânica, nalguns casos anteriores ao domínio romano. Na nossa comunicação procuraremos destacar os elementos mais significativos desta realidade, fundamentalmente caracterizada pela integração de uma área atlântica, com vivazes características específicas, na economia de um grande império centrado no Mediterrâneo.

Palavras chave:

Atlântico, Mediterrâneo, Romanização,

\section{Abstract:}

The main harbors of the Sado in Roman times, Salacia, Caetobriga and Tróia, allow us to approach, as a result of their privileged location in the western façade of Hispania, the always debated theme of Romanization. The study of these harbors, all different in their status, despite serving the economic activities typical of the region, show how were combined, throughout eighteen or twenty generations, factors typical of the Atlantic world with the novelties and dynamics of Mediterranean origin, in some cases preceding the roman domain. In our paper we will highlight the most significant elements of this reality, fundamentally characterized by the integration of an Atlantic region with a specific economy in a large empire centered in the Mediterranean.

Keywords:

Atlantic, Mediterranean, Romanization, Sado. Sado.

\footnotetext{
* In Memoriam João Carlos Lázaro Faria.
} 
O estudo dos portos romanos do Sado, cuja importância na Lusitânia é facilmente aceite pelos investigadores, arqueólogos ou não, conta com uma longa tradição, responsável por uma bibliografia volumosa, nacional, estrangeira e mista, ainda que de desigual valor e nem sempre consensual, como aliás é, ou devia ser, normal no âmbito da verdadeira investigação científica ${ }^{1}$. Dois portos sadinos mereceram durante muito tempo o privilégio da atenção dos investigadores, por razões que se prendem fundamentalmente com a abundância de testemunhos materiais neles existentes, como é o caso de Alcácer do Sal e, sobretudo, de Tróia. Na verdade, o reconhecimento de Setúbal como terceiro porto do complexo que incluía os dois anteriores só aconteceu tardiamente, permanecendo mesmo em publicações menos cuidadas a velha identificação de Caetobriga com as ruínas da península de Tróia. A investigação em Setúbal é praticamente contemporânea daquela que permitiu um conhecimento muito razoável, ainda que incompleto e exigindo longa continuidade, de Alcácer do Sal na época romana.

A visibilidade das ruínas e o enigmático topónimo local despertaram cedo a curiosidade dos eruditos em relação ao sítio de Tróia, levando-os durante muito tempo a uma identificação com a Caetobriga das fontes antigas. No século XVII o cartógrafo Pedro Teixeira Albernaz dizia de Tróia o seguinte: Se veen unas ruinas de grandes ydefiçios y se tiene averen çido de una gran ciudad que fue fundada de los troyanos a devoçión de su troia. Y oi se conserba este mismo nombre en estas ruinas, llamandole Troia ${ }^{2}$. Assim, dos três portos que referimos nesta comunicação o de Tróia, de ignota designação antiga, foi o primeiro a merecer investigação arqueológica, logo no século XVIII, por iniciativa da futura rainha D. Maria I, depois, por meados do século XIX, da responsabilidade da Sociedade Arqueológica Lusitana ${ }^{3}$.

Foi também em Tróia, que visitámos pela primeira vez em 1966 (Fig. 1), que teve lugar em 1959 uma campanha de arqueologia subaquática, pioneira no

1 Este artigo resulta da comunicação apresentada ao I Encontro de Arqueologia e História de Alcácer do Sal, realizado em Maio de 2009. Agradecemos cordialmente ao Dr. Luís Madeira a preparação das figuras que apresentamos. Abreviaturas no texto: Corpus Inscriptionum Latinarum, Berlim = CIL; Realencyclopädie der Classischen Altertumswissenschaft, Estugarda = RE; Hispania Antigua Epigraphica, Madrid = HAE; Inscrições Romanas do Conventus Pacensis, Coimbra $=I R C P$.

2 F. Pereda / F. Marías, El Atlas del Rey Planeta. La "Descripción de España y de las Costas y Puertos de sus Reynos” de Pedro Texera (1634), Hondarribia, Editorial Nerea, 2002, p. 240.

3 C. T. Silva / J. Soares, Arqueologia da Arrábida, Lisboa, Serviço Nacional de Parques, 1986, pp. 162-166. 


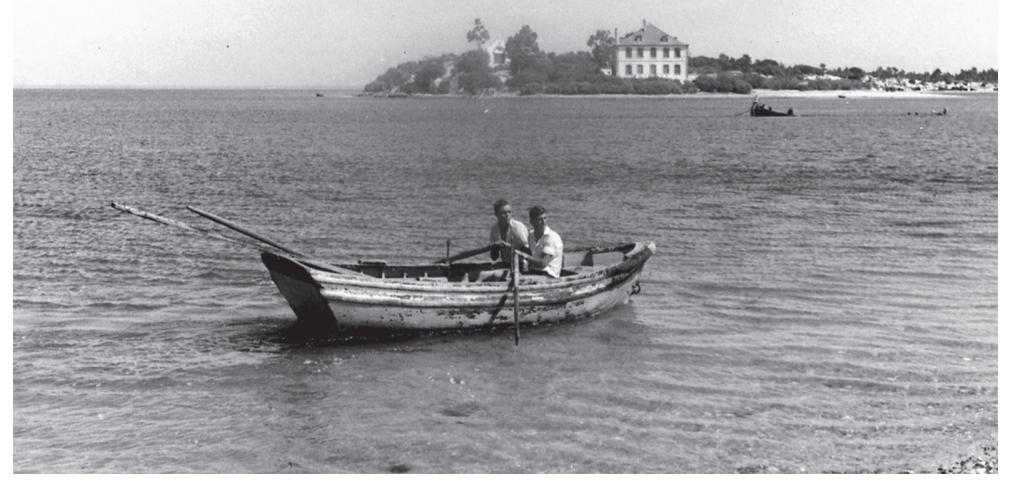

Fig. 1 - A ponta de Tróia e a Caldeira em Agosto de 1966

nosso país ${ }^{4}$. O sítio, cuja exploração ao longo do século passado não foi isenta de vicissitudes diversas e alternou actividade e longos períodos de marasmo, motivou algumas fortes polémicas. Referimos uma delas, ocorrida no último quartel do século XIX, quando um investigador francês, M. de La Fontaineau, negou a importância do sítio arqueológico e dos achados que nele se tinham registado, quase acusando os estudiosos portugueses de fraude científica ${ }^{5}$. Este episódio é particularmente curioso e merece ser lembrado atendendo ao papel desempenhado por arqueólogos franceses nos trabalhos de investigação desenvolvidos em Tróia e no estuário do Sado nas últimas duas décadas.

Diferentes foram os percursos da investigação em Alcácer do Sal, cuja condição de invulgar port of trade antigo foi muito cedo posta em relevo pelos achados da necrópole do Senhor dos Mártires, designação que talvez resulte de uma primitiva explicação para a presença das sepulturas, e pelos

4 Os trabalhos de prospecção subaquática em 1959 foram orientados por Manuel Heleno e realizados por uma equipa de mergulhadores do Centro Português de Actividades Submarinas e do Batalhão de Sapadores Bombeiros (Lisboa). Foi pesquisada uma área entre a Caldeira e o sítio das Baleias, confirmando-se a existência de muros submersos e recolhida muita cerâmica. Estes trabalhos foram precedidos, em 1957, por uma intervenção menor, integrada num campo de trabalho da Mocidade Portuguesa.

5 E. de Fontaineau, La verité sur la question archéologique de Cetóbriga en Portugal, Bordéus, 1875. 
testemunhos numismáticos (Fig. 2), sem que tal contribuisse significativamente para estimular projectos de investigação sistemáticos, que acabaram por se desenvolver tardiamente, tal como sucedeu em Setúbal, em grande parte relacionados com a execução de obras públicas ou privadas. Não podemos deixar de assinalar o relevante contributo da epigrafia, atendendo à escassez de fontes literárias antigas, para um melhor conhecimento da demografia e da estrutura social do Baixo Sado na época romana, destacando-se, naturalmente, o insubstituível trabalho de José d'Encarnação ${ }^{6}$.
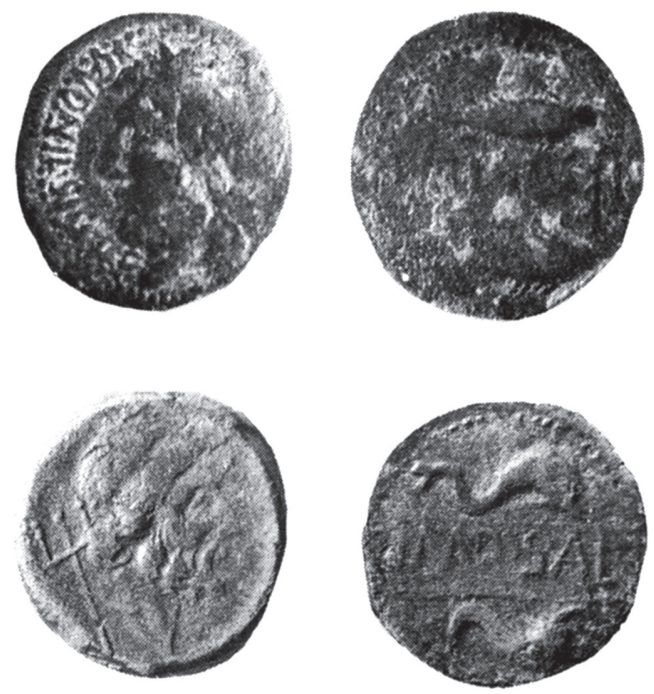

Fig. 2 - Moedas com legenda ibérica (Bevipo) e com legenda latina (Salacia)

Depois deste pequeno preâmbulo, ditado pela falta de uma historiografia da investigação arqueológica regional, sempre útil e plena de ensinamentos para o presente e, talvez, para o futuro, passaremos de imediato ao tema que pretendemos desenvolver, que é o de analisar a forma como nos três principais portos romanos do Sado interagiram as realidades atlânticas e os influxos mediterrânicos. Para o observador avisado não será difícil concluir que a região sadina que nos interessa conheceu fenómenos de longue durée em que circunstâncias aparentemente conjunturais se repetem regularmente,

6 José d'Encarnação, Inscrições Romanas do Conventus Pacensis, Coimbra, Faculdade de Letras, 1984, pp. 251-292, 743-744. 
determinando uma espécie de dialéctica Norte-Sul, num cenário de persistentes e naturais relações atlântico-mediterrânicas.

Uma exagerada compartimentação dos diferentes períodos históricos e o conceito vigente até quase aos finais do século passado de que o litoral ora português não era mais do que um finisterra sem interesse ou quase sem interesse, fracamente relacionado com o Mediterrâneo e isolado das margens atlânticas mais promissoras da Gália e da Britânia, isto mesmo na época imperial romana. Os progressos verificados través da investigação arqueológica nos últimos 20 anos permitem hoje uma visão nova do que foi o litoral português no período das chamadas colonizações fenícia e púnica e, depois, como fenómeno de continuação e ampliação, na época romana ${ }^{7}$. O Sado teve um lugar primordial neste processo de reconstrução da história, reflectindo quer o evidente valor económico da região, quer uma circunstância de ordem geográfica, nem sempre valorizada pelos investigadores, que coloca os estuários do Sado e do Tejo praticamente no limite setentrional da área mais regularmente frequentada pela navegação mediterrânica, vocacionando os seus centros portuários como portos de escala de uma navegação de longo curso e como portos de reunião e de ruptura de cargas.

É usual, ultimamente, apresentar o porto de Mértola (Myrtilis) como o último porto mediterrânico, sugestiva denominação honorífica totalmente desprovida de verdade, pois nem na Idade do Ferro, nem na Antiguidade Tardia, e menos ainda no período romano, tal aconteceu. Com efeito, não é possível limitar a esta cidade, mesmo durante a chamada Antiguidade Tardia, a frequência regular e significativa da navegação mediterrânica e a presença de materiais atribuíveis a essa navegação, nomeadamente os de origem oriental. A actividade de comerciantes orientais em Lisboa (Olisipo) e o registo de materiais como a Late Roman $\mathrm{C}$ em sítios não muito afastados da fachada atlântica, como Braga, obrigam a recusar a Mértola a pretendida condição de marca extrema da navegação mediterrânica no Atlântico ${ }^{8}$. Os progressos da arqueologia urbana olisiponense não deixarão de confirmar, como recentemente aconteceu, que

7 A. González-Ruibal, "Facing two Seas: Mediterranean and Atlantic. Contacts in the North-West of Iberia in the First Millenum BC", Oxford Journal of Archaeology, 23, 3 (2004), pp. 287-317.

8 L. G. Moreno, "Colónias de comerciantes orientales en la Península Ibérica. S. V-VII", Habis, 3 (1972), pp. 127-154; B. W. Cunliffe, Facing the Ocean. The Atlantic and its Peoples, Oxford, Oxford University Press, 2002, pp. 478-481, 582. 
a classificação de último porto mediterrânico que lhe foi atribuída no século passado é igualmente válida para a época romana ${ }^{9}$.

Esta circunstância, que nos parece inquestionável, foi de alguma forma sugerida pela geografia antiga, que situava o limite entre o Oceano e o Mar Gálico a norte do Cabo da Roca ${ }^{10}$, não se afastando significativamente do limite que os geógrafos consideram existir em Portugal entre a zona de influência mediterrânica e a de influência atlântica ${ }^{11}$. Esta dicotomia Norte / Sul assinalável em todos os períodos da nossa história, não elimina, como é evidente, uma consistente dinâmica de relações inter-regionais. Talvez, de forma um tanto imprecisa, possamos definir o nosso país como uma região atlântica de cultura mediterrânica fortemente marcada pelo atlantismo dos que sempre aqui estiveram e de outros que foram chegando ao longo dos tempos.

Os portos do Sado situam-se numa área onde as condições naturais implicaram muito cedo contactos privilegiados com o Mediterrâneo. Na época romana essas condições ditaram a estratégia seguida na urbanização do território, onde as cidades privilegiadas se limitam até quase aos finais do século I, à linha do Tejo (Fig. 3). Salacia foi uma dessas poucas cidades distinguidas na hierarquia urbana romana, apesar de, por razões ainda mal conhecidas, ter perdido a favor de Olisipo a primazia que conheceu até ao colapso da República. Julgamos que neste processo, no qual os factores de ordem natural nos parecem secundários, para além de razões de ordem política, influiu a função de último porto mediterrânico desempenhada por Olisipo, melhor adaptada que qualquer outra cidade portuária a constituir o ponto de contacto da navegação setentrional e da navegação meridional, destinada aos portos da Bética ou ao Mediterrâneo. Esta autêntica mais-valia do porto olisiponense é posta em relevo por muitos autores. Em 1804, Francisco do Nascimento Silveira deixou-nos um bom exemplo do que dizemos: Nesta grande capital forma o Tejo o maior Empório da Europa: unindo nele pela navegação, tanto as Nações dentro do Báltico, como as Asiáticas, e Mediterrâneas ${ }^{12}$. Seja como for, os portos do Sado estão perfeitamente situados no sector frequentado

9 V.G. Mantas, "O porto romano de Lisboa”, in G. P. Berlanga / J.P. Ballester (ed.), Puertos Fluviales Antiguos: Ciudad, Desarrollo y Infraestructuras, Valência, Universitàt deValència, 2003, pp. 13-29.

${ }^{10}$ Plínio, N.H., 4, 114; Solino, 23, 5. Theodor Mommsen, na sua edição de Caius Iulius Solinus, considerava ter este autor utilizado material do escritor lusitano Bochus: Th. Mommsen, C. Iulius Solinus De Mirabilibus Mundi, Berlim, Weidmann, 1895.

${ }^{11}$ O. Ribeiro, Geografia de Portugal, II, Lisboa, Sá da Costa, 1987, pp. 452-461.

${ }^{12}$ L. N. Silveira, Mapa breve da Lusitânia Antiga e Galiza Bracarense, Lisboa, Simão Tadeu Ferreira, 1804, pp. 66-67. 


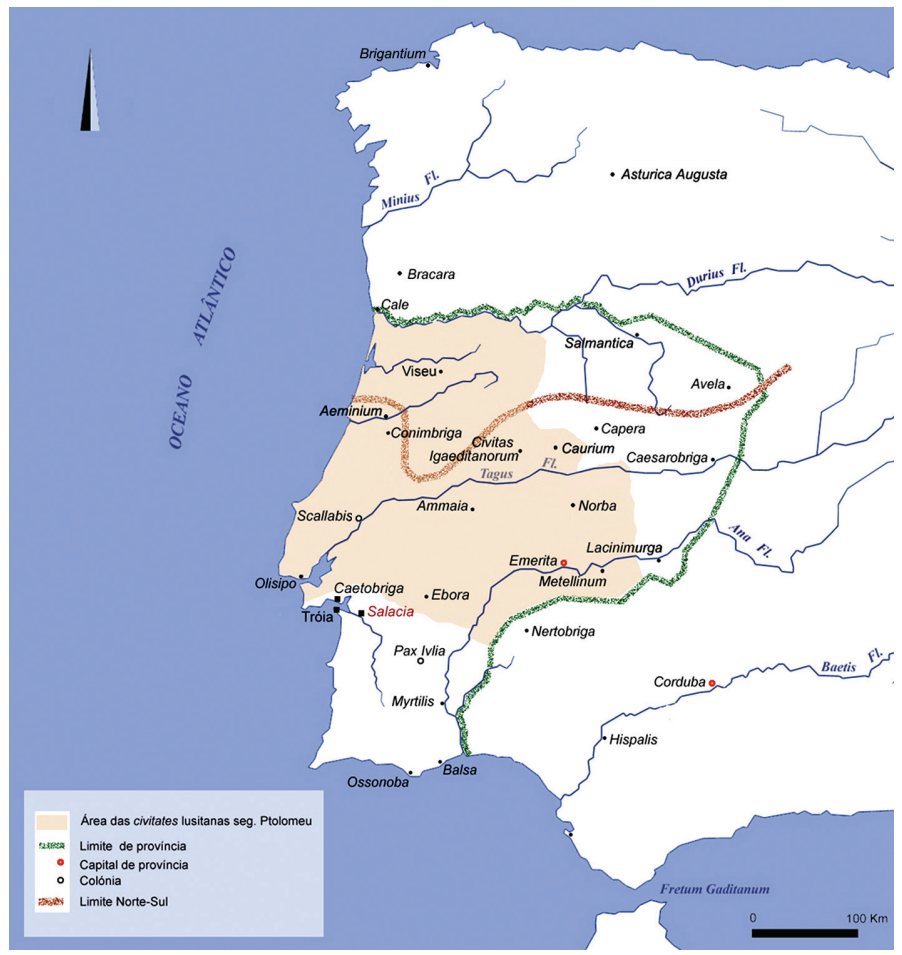

Fig. 3 - Os portos do Sado e as cidades privilegiadas da Lusitânia no início da Era

pela navegação mediterrânica, independentemente da sua condição atlântica e população predominantemente indígena, reflectindo a situação de interface do litoral lusitano. O estratega naval Alfred Mahan não deixaria de reconhecer as potencialidades oferecidas pela região no contexto da navegação antiga ${ }^{13}$.

O texto da Ora Maritima, tantas vezes discutido e interpretado, pode considerar-se como a descrição mais antiga da costa portuguesa. Sem que as identificações propostas para determinados acidentes do litoral possam ser consideradas como dados adquiridos, é claro encontrarem-se no texto referências ao estuário do Sado, onde a ponta de Tróia seria, na altura, uma ilha ${ }^{14}$. A integração do litoral ocidental atlântico da Ibéria, na zona de influência mediterrânica é, pois, muito anterior à chegada dos Romanos, como largamente

${ }^{13}$ A posição geográfica é um dos seis requisitos básicos considerados por Mahan (1840-1914), um dos maiores pensadores navais de todos os tempos, para desenvolver poderio através do uso do mar.

${ }^{14}$ Avieno, Or.Mar., 173-201. 
demonstram os testemunhos de um comércio institucional caracterizado pela importação de objectos e produtos de prestígio e pela exportação, em larga escala, de matérias-primas. O estabelecimento de núcleos estáveis de população oriental, sobretudo em feitorias como as de Santa Olaia, Lisboa, Almaraz ou Abul, contribuiu para o nascimento de um horizonte orientalizante em que as populações indígenas tiveram um papel activo, alargando-se o chamado Círculo do Estreito e preparando, sob não poucos aspectos, o êxito da romanização em vastas áreas da Lusitânia ${ }^{15}$.

A ligação da província lusitana aos grandes centros económicos da Bética, dominados até ao século III por Cádis (Gades), ligação que perdurou durante todo o Alto Império, reflecte uma situação de continuidade, ressalvando, como é evidente, as alterações introduzidas pelas realidades da ordem romana, uma das quais, e não das menos importantes, foi a abertura de um espaço económico muito maior e a multiplicação das necessidades públicas e privadas a que a Península Ibérica devia prover. Minérios e produtos alimentares vão constituir o grosso das exportações, conhecendo os portos sadinos redobrada actividade durante o domínio romano, sobretudo em relação aos últimos, com os preparados piscícolas em grande destaque. Não podemos esquecer, como por vezes acontece, que o valor do bronze na época romana não decresce, nem assim poderia ser, atendendo às características e dimensões do Império, pelo que as velhas rotas marítimas do estanho não decaíram, circunstância que os portos da faixa atlântica ocidental não deixaram de explorar convenientemente, que mais não fosse como escalas obrigatórias dessa navegação de longo curso, desde logo suficiente para explicar a grande dimensão, segundo Estrabão, dos navios que iam da Turdetânia à Itália, navios atlânticos ${ }^{16}$.

A constituição de uma longa frente marítima atlântica, sem solução de continuidade entre Marrocos e o Mar do Norte, tornada uma realidade no principado de Cláudio e reforçada pela conquista da Britânia, da maior importância para ampliar os benefícios da rota de longo curso servida pelos portos lusitanos, representou um acontecimento de grande significado, e não apenas político ${ }^{17}$.

${ }^{15}$ A. M. Arruda, "Orientalismo e Orientalizante. Génese e aplicação de um conceito na Idade do Ferro do Centro / Sul de Portugal”, in J. V. Serrão (coord.), Homenagem a Jorge Borges de Macedo, Lisboa, Instituto Nacional de Investigação Científica, 1992, pp. 34-38; A. M. Arruda / R. Vilaça, "O mar greco-romano antes de Gregos e Romanos. Perspectivas a partir do Ocidente peninsular”, in F. Oliveira / P. Thiercy / R. Vilaça (coord.), O Mar Greco-Romano, Coimbra, Imprensa da Universidade, 2006, pp. 271-289.

${ }^{16}$ Estrabão, 3, 2, 6.

${ }^{17}$ G. C. García, "Roma y el mar: del Mediterraneo al Atlántico", in V. Alonso (coord.), Guerra, Exploraciones y Navegación, Ferrol, Universidade da Coruña, 1995, pp. 78-83. 
Sem que se esqueça a importância do transporte de produtos hispânicos para os copiosos efectivos romanos empenhados de forma permanente, no Reno e na Britânia, através do Mediterrâneo e dos rios gauleses, a verdade é que o custo do transporte pela rota continental era de tal forma elevado que, mesmo tratando-se de abastecimentos militares e não de simples comércio civil, a administração romana não deixaria de recorrer à rota atlântica, infinitamente mais barata, ainda que considerada mais perigosa ${ }^{18}$, tal como já acontecera com o abastecimento das tropas romanas envolvidas na conquista e pacificação do Norte peninsular no principado de Augusto, como parece testemunhar o carregamento de ânforas Haltern 70 do sítio submarino dos Cortiçais, em Peniche.

O equipamento dos portos, pouco ou nada conhecido, em parte por quase todos serem portos naturais, flúvio-marítimos, dispensando trabalhos de organização e defesa dos planos de água, reflectiria, juntamente com a construção de faróis, o valor acrescido da rota atlântica na grande estratégia do Império. Na faixa atlântica ocidental conhecem-se seguramente três faróis romanos, um em Cádis, outro em Chipiona, na foz do Guadalquivir, ambos desaparecidos, e o grande farol da Corunha, a célebre Torre de Hércules, obra de um arquitecto lusitano levantada pelos finais do século I, o que permite situá-lo no contexto da rota britânica ${ }^{19}$. Estrabão faz referência, numa passagem da Geografia um tanto prejudicada, a uma torre, denominação habitual para os faróis, situada junto à foz do Sado, provavelmente no Outão, circunstância suficiente para demonstrar a importância da zona no início do Império ${ }^{20}$. $\mathrm{O}$ facto de a maioria dos faróis romanos indicar o ponto de aterragem ou a localização do porto, associado à prática da navegação nocturna, própria das rotas de longo curso, obriga a considerar a existência e a frequência regular de tais rotas, cujo impacte sobre os centros portuários com elas relacionados foi, sem dúvida, muito relevante, dos pontos de vista económico e cultural.

$\mathrm{O}$ desenvolvimento de actividades produtivas em larga escala no Baixo Sado não deixou de beneficiar deste tipo de equipamentos, provavelmente presentes noutros locais da costa lusitana, como terá mesmo influenciado a sua construção, por razões eminentemente pragmáticas. A faixa atlântica lusitana, mesmo admitindo a preponderância de relações mediterrânicas e apesar da escassez de vestígios garantidos de instalações portuárias, anima-se

${ }^{18}$ K. Greene, The Archaeology of the Roman Economy, Londres, Batsford, 1986, pp. 40-41.

${ }^{19}$ S. Hutter / Th. Hauschild, El faro romano de La Coruña, Corunha, Edicios do Castro, 1994. Continuamos a atribuir a construção do farol ao arquitecto eminiense G. Sevius Lupus (CIL II 2559).

${ }^{20}$ Estrabão, 3, 3, 1. 
singularmente, afastando-se da imagem clássica do finisterra inóspito e quase deserto. O Oceano representou sempre um topos de grande significado na ideologia imperial romana, interpretando-se as suas margens como limite natural de um Império Universal, como tal limite do mundo civilizado ${ }^{21}$. O litoral lusitano superou essa condição geográfica, oferecendo o suporte dos seus portos a uma navegação que, independentemente do seu destino final, era atlântica. Para compreendermos melhor a forma como as actividades marítimas se desenvolveram na Lusitânia e as funções desempenhadas pelos portos sadinos devemos ter em conta os diferentes níveis do comércio marítimo romano, parte do qual, o de maior volume e significado provincial, dependia largamente da intervenção estatal, através de entidades como a Annona. Julgamos que a economia comportava três escalões, local, regional e imperial propriamente dito. Estes escalões, todavia, não se excluem mutuamente, antes pelo contrário surgem frequentemente associados e com características de complementaridade.

Assim, se a cabotagem serviu à difusão de produtos regionais ou importados através de um porto lusitano, também serviu à concentração de produtos destinados à exportação para a Itália ou para os exércitos, segundo uma característica própria do comércio marítimo antigo. A enorme exportação de preparados piscícolas a partir do Sado implicava, cremos, meios de transporte locais, que devem ter conhecido ampliação ao longo do tempo. Este volume de exportações, assegurado pelos achados de ânforas em diversas regiões do mundo romano, exigia capturas só possíveis com uma frota pesqueira numerosa, dependente de portos e de abrigos situados na região. Embora a existência de armações para a captura do atum, por exemplo, seja mais do que uma possibilidade, antecedendo a chegada dos Romanos, a verdade é que pouco ou nada sabemos sobre as embarcações e técnicas de pesca e menos ainda sobre os pescadores. Pelo contrário, o nosso conhecimento sobre fornos de ânforas e ânforas, inclusive através de achados subaquáticos, é muito generoso ${ }^{22}$, a ponto de fazer esquecer outros aspectos que permitiriam uma avaliação mais correcta do que algumas até agora publicadas ${ }^{23}$.

${ }^{21}$ V. G. Mantas, "O Atlântico e o Império Romano", Revista Portuguesa de História, 36, 2 (2003), pp. 445-467.

22 C. Fabião, “A exploração dos recursos marinhos”, in A. Alarcão (dir.), Portugal Romano. A Exploração dos Recursos Naturais, Lisboa, Museu Nacional de Arqueologia, 1997, pp. 35-58.

${ }_{23} \mathrm{~J}$. Edmondson, Two Industries in Roman Lusitania. Garum and Mining, Oxford, British Archaeological Reports, 1987, pp. 152-154, 186-190; R. Étienne / F. Mayet, "La place de la Lusitanie dans le commerce mediterranéen", Conimbriga, 32-33 (1994), pp. 201-218. 
Não é possível duvidar da existência de uma activa vida fluvial e marítima a partir dos portos sadinos, em larga medida obscurecida pela infeliz falta de informações existente sobre construção naval, que conta com testemunhos medievais e modernos, transportes fluviais, cabotagem e origem dos navios, que durante o Alto Império podiam ter os principais portos de armamento na Bética. Apesar da importância do porto olisiponense, o volume de produção de preparados piscícolas do Sado parece-nos ser suficiente para que grande parte da exportação se fizesse directamente a partir do estuário, o que obrigava a concentrar a produção dos múltiplos estabelecimentos de salga, grandes e pequenos, dispersos na região, a partir dos diferentes pontos de embarque no rio. A este movimento temos que acrescentar o que resultava das necessidades de abastecimento de matérias-primas aos fornos e às cetárias. Quer isto dizer que, apesar dos progressos conseguidos pela investigação nas últimas décadas, estamos muito longe de conseguir um cenário equilibrado das actividades flúvio-marítimas desenvolvidas na época romana, que devem ser consideradas parte de um processo evolutivo nos portos sadinos. Depois de tudo, a imagem que nos chega, muito incompleta, relaciona-se mais com o escalão superior da economia romana e com as gentes nele envolvidas do que com as actividades primárias que o sustentam. É claro que garum e similares não constituíram a totalidade dos produtos exportados a partir do Sado, mas sobre os restantes, como as lãs de Salacia lembradas por Estrabão e Plínio ${ }^{24}$, não vale a pena teorizar. Sobre os minérios podemos esperar vir a ter mais dados, sobretudo a partir do mar, quando a prospecção arqueológica subaquática, eventualmente com o inestimável apoio da Armada, ganhar a capacidade de que necessita e merece, muito longe de possuir neste momento.

Para complicar mais o panorama, verifica-se que, assim como as minas entram em decadência no século III, pela mesma época os testemunhos epigráficos, essenciais para reconstituir a estrutura social dos portos, sofrem uma quebra generalizada, quase desaparecendo, mais por razões de ordem política e cultural do que por causas económicas. Esta circunstância coincide com as alterações, sugeridas pela arqueologia, na organização do comércio marítimo de longo curso, com uma nítida valorização das rotas orientais e africanas. Quanto à rota atlântica, muito dependente de factores militares relacionados com a Britânia ${ }^{25}$, para onde a maioria dos navios navegaria directamente a

\footnotetext{
${ }^{24}$ Estrabão, 3, 2, 6; Plínio, N.H., 8, 191.

${ }^{25}$ C. C. Monfort, "Britannia and the Imports of Baetican and Lusitanian Amphorae", Journal of Iberian Archaeology, Vol.0 (1998), pp. 159-170; C. Fabião, “A dimensão atlântica da Lusitânia: periferia ou charneira no Império Romano?”, in J.-G. Gorges / J. d'Encarnação / T. Basarrate /
} 
partir da Corunha (Brigantium), sem escalas intermédias, o que explicaria a limitada representatividade dos materiais lusitanos na cornija cantábrica e na Aquitânia, pode ter conhecido algum decréscimo no Baixo Império ${ }^{26}$. Este decréscimo de actividade talvez tenha resultado das alterações na ordem de batalha do exército romano na fronteira norte, tanto como de alterações no padrão de recrutamento das tropas, cada vez menos dependentes de hábitos alimentares mediterrânicos. Todavia, esta possível quebra no tráfico teve alguma compensação no desenvolvimento simultâneo da Calécia ${ }^{27}$, como os achados no mar e em terra claramente sustentam.

No complexo portuário constituído por Salacia, Caetobriga e Tróia, o primeiro destes centros, para além da sua antiquíssima função de porto flúvio-marítima, comparável à de Olisipo, surge como capital administrativa de um território no qual Caetobriga e Tróia podem ser classificadas como aglomerações secundárias, a primeira de clara fundação pré-romana, a segunda surgida, aparentemente, no século I. Para além das comunicações por via aquática que uniam os três portos referidos, Caetobriga e Salacia situavam-se directamente sobre a grande estrada romana, em parte sucessora do célebre caminho tartéssico que se estendia entre o estuário do Tejo e o Guadiana, Olisipo-Caetobriga-Salacia, dirigindo-se depois a Emerita, por Ebora, e a Myrtilis, por Pax Iulia ${ }^{28}$.

Ptolomeu coloca entre os Turdetani, imediatamente limítrofes aos Lusitani, os três portos sadinos. Podemos, pois, admitir que a fronteira norte do município salaciense corresponde ao limite entre estes dois povos, o qual, nesta região, a partir do Cabo Espichel, coincidia igualmente com a divisória entre o convento escalabitano e o convento pacense ${ }^{29}$. Considerando que a maior parte da população da região era indígena, talvez valha a pena recordar, uma vez mais, o quanto é difícil, através do registo arqueológico, identificar diferenças entre uns e outros. Na verdade, através dos testemunhos arqueológicos não é possível, a não ser, talvez, valorizando características muito específicas da

A. Carvalho (coord.), Lusitânia Romana.Entre o Mito e a Realidade, Cascais, Câmara Municipal, 2009, pp. 53-74.

${ }^{26}$ J. N. López, El comercio antigo en el N.W. peninsular. Lectura histórica del registro arqueológico, Corunha, Museo Arqueologico, 1991, p. 193; C. F. Ochoa (ed.), Gijón Puerto Romano. Navegación y Comercio en el Cantábrico durante la Antigüedad, Barcelona-Madrid, Lunwerg Editores, 2003.

${ }^{27}$ J. Alarcão, O domínio romano em Portugal, Mem Martins, Europa América, 1989, pp. 60-61 (= Alarcão, Domínio).

${ }^{28}$ V. G. Mantas, "Vias e portos na Lusitânia romana", in J.-G. Gorges / E. Cerrillo / T. Nogales (ed.), Las Comunicaciones en Lusitania Romana, Madrid, Ministerio de Cultura, 2004, pp. 430, 445-447.

${ }^{29}$ Ptolomeu, 5, 2. 
vida económica, apontar diferenças entre um turdetano e um lusitano, na época romana, isto passando por alto a debatida questão do celtismo dos Lusitanos. A onomástica pré-romana, conhecida através da epigrafia do período romano, pertence ao que se costuma designar como antroponímia lusitana, bem representada no convento pacense ${ }^{30}$. Quanto à toponímia, apenas podemos recorrer, na época romana, ao topónimo Caetobriga, cujo sufixo -briga leva a situá-lo no imponente grupo de topónimos célticos com idêntica terminação e conhecido significado ${ }^{31}$.

Como é normal, a população portuária mostra uma tendência, acentuada por vezes, para uma certa mistura, neste caso concreto do Sado perfeitamente justificada pela sua antiga abertura a elementos exóticos e pela consequente mobilidade provocada por uma economia activa, capaz de motivar uma dinâmica social integradora. Este processo é muito anterior ao domínio romano, durante o qual ganhou nova complexidade. A presença de elementos orientais ou norte-africanos, de ascendência fenício-púnica, na população regional da época romana é uma certeza, embora os testemunhos onomásticos não abundem, circunstância que se repete noutros locais, inclusive na cidade de Gades, onde apenas se conhece um nome semita ${ }^{32}$. Estamos perante o resultado da romanização onomástica da população, que terá agido mais rapidamente sobre determinados grupos. Nomes latinos e nomes gregos poderão, como veremos, ocultar a verdadeira origem étnica ou cultural dos seus detentores. Na região salaciense, uma das famílias dominantes no século I, a dos Bocchi, comemorados em várias inscrições e à qual pertencia, tudo leva a crer, o erudito Bocchus referido por Plínio ${ }^{33}$, representa descendentes, recentes ou antigos, da colonização fenício-púnica, neste caso com claríssimas ligações ao Norte de África.

A epigrafia sofre da desagradável tendência de ilustrar especialmente as camadas superiores da população, sem que possamos esquecer que possuímos apenas uma amostra do que um dia existiu. Não devemos pedir-lhe o que não nos pode dar, sob risco de traçarmos relatos interessantes e de moda, totalmente afastados da realidade. Uma epígrafe de Salacia, todavia, permite vislumbrar o processo de inclusão da sociedade indígena, entenda-se dos seus notáveis, na ordem política e cultural romana nos primeiros tempos do Império.

${ }^{30}$ Encarnação, p. 777.

${ }^{31}$ M. L. Albertos, “Los topónimos em -briga en la Hispania”, Veleia, 7 (1990), pp. 131-146; F. Villar, Indoeuropeus y no Indoeuropeus en la Hispania prerromana, Salamanca, Ediciones Universidad, 2000, pp. 33, 441-442.

${ }^{32}$ Cícero, Pro Balb., 50.

${ }^{33}$ Plínio, N.H, 34, 158; 37, 24. 
Embora publicada e comentada muitas vezes, permitimo-nos relembrá-la neste momento: Imp. Caesari. Divi. F. Augusto / Pontifici. Maxumo. Cos. XII / Trib. Potestate. XVIII / Vicanus. Bouti. F. / Sacrum (CIL II $5182=$ IRCP 184). A inscrição reveste-se de características que permitem considerá-la uma devotio pessoal, inclusive atendendo à sua datação, 5-4 a.C., alta em termos de desenvolvimento do culto imperial na Lusitânia.

É muito interessante o reflexo do estádio inicial da integração de um sector da população indígena, ainda em vias de romanização, que o monumento transmite. Como já foi dito, trata-se de uma fase precoce da romanização onomástica, combinando-se um nome latino, Vicanus, com uma filiação peregrina, Bouti(i). $F\left(\right.$ ilius), inserindo-se o nome do pai na antroponímia céltica ${ }^{34}$. A inscrição evidencia uma clara tentativa de promoção social do elemento indígena, céltico, aparentemente pouco sucedida em relação aos elementos exógenos da sociedade salaciense, que encontraremos bem representados, pouco depois, a nível das magistraturas locais. Este apagamento do elemento indígena parece corresponder a uma sociedade em que economia e poder caíram nas mãos de elementos estranhos à população original, representante do mundo atlântico. Esta situação de subalternidade pode ter conhecido alguma alteração positiva nos finais do século I, como sugere a ara consagrada a Júpiter pela flamínia Flávia Rufina (CIL II 32 = IRCP 183), em resultado da concessão do direito latino à Hispânia por Vespasiano, mas esta personagem é de origem emeritense. Como dissemos, a falta de testemunhos epigráficos a partir do século III dificulta o estudo do que possa ter acontecido no Baixo Império, quando não é irrelevante considerar a afirmação de regionalismos e um certo revivalismo indígena. Na verdade, e resumindo o que pretendemos dizer, verifica-se que no Corpus levantado por José d'Encarnação não consta, para toda a região, nenhum outro nome indígena a não ser o que ocorre no monumento consagrado por Vicanus ${ }^{35}$, o que, mesmo considerando o grau de romanização da população da área, é muito significativo (Fig. 4).

Aprofundemos um pouco a análise dos dados epigráficos, limitada pela ausência de achados em Setúbal. Esta circunstância também se revela esclarecedora, deixando Caetobriga, povoação pré-romana não integrada na restrita ordem urbana romana, fora do horizonte epigráfico do Baixo Sado, contrariamente ao que se verifica em Salacia e em Tróia. É certo que os acasos que tão frequentemente regulam os achados arqueológicos poderão ter algo

${ }^{34}$ Encarnação, pp. 194, 296; J. M. Abascal, Los nombres personales en las inscripciones latinas de Hispania, Madrid-Murcia, Universidad de Murcia, 1994, pp. 303-304.

${ }^{35}$ Encarnação, pp. 251-292. 


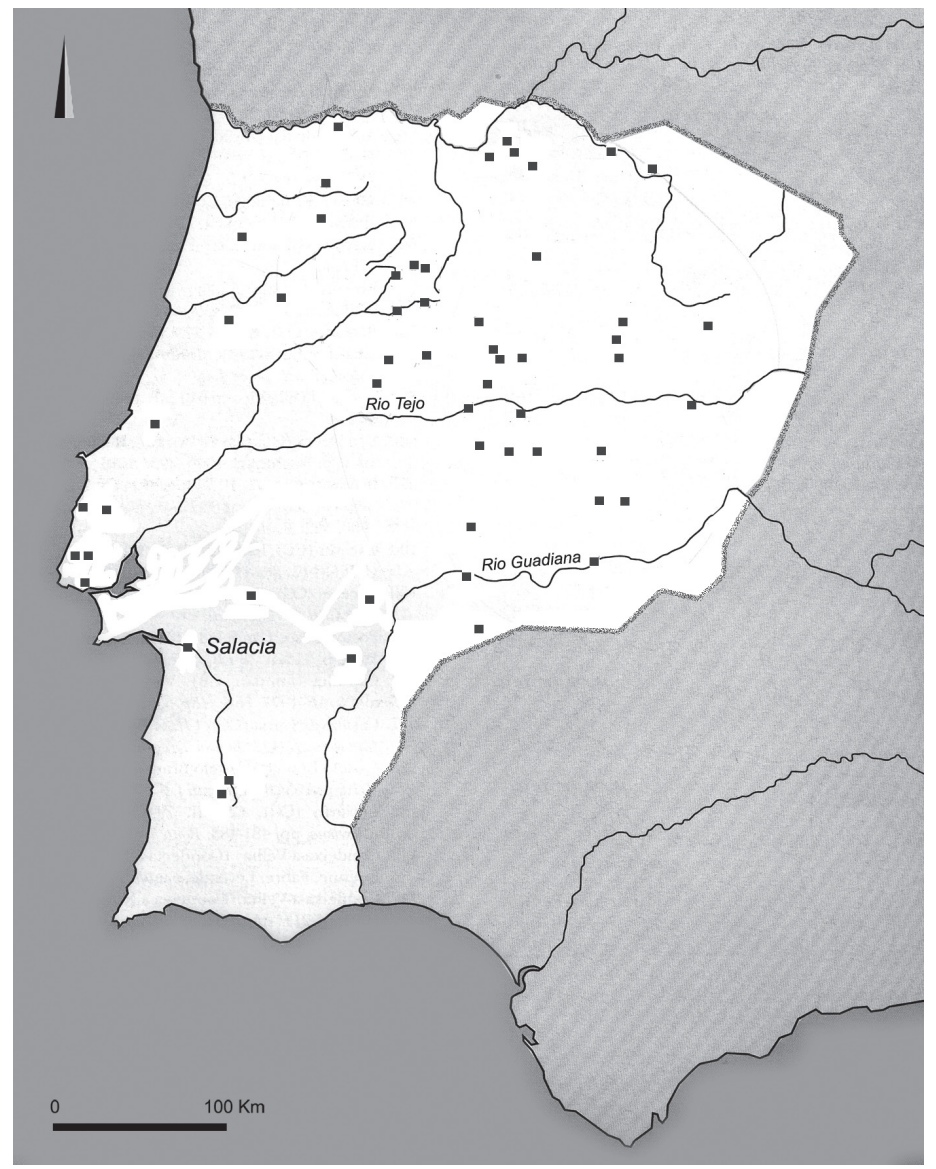

Fig. 4 - Distribuição epigáfica dos Boutii no território lusitano

a ver com esta situação um tanto anormal, mas não explicam uma diferença desta envergadura. Não menos interessante indicador da estrutura da sociedade luso-romana dos portos sadinos é o que a análise estatística da repartição dos nomes latinos e dos cognomina gregos em Salacia, em Tróia e no meio rural, mostra. Em Salacia estão representadas as famílias Apuleia, Cornelia,Duronia, Iulia, Iunia, Octavia, Porcia e Sulpicia; em Tróia as famílias Aponia, Attia, Cornelia, Iulia, Licinia, Maria, Paccia, Servilia e Vibia; nos campos ocorrem testemunhos seguros das famílias Flavia, Iulia, Maria e Rubria. De todas estas famílias, embora com muito menor representação do que em Olisipo, Ebora ou Pax Iulia, apenas a Iulia se identifica na capital do município, em Tróia (um liberto) e nos campos. Neste caso, mais uma vez deparamos com a ubiquidade das clientelas de César e, sobretudo, de Augusto, na Lusitânia 
meridional ${ }^{36}$. Segue-se-lhe a Cornelia, a grande família dos Bocchi, em Salacia e em Tróia, enquanto a Maria se identificou neste vicus e, no campo, em S. Romão do Sado (IRCP 194-195), todas possibilitando relações com o Sudoeste da Península Ibérica, onde, em Sevilha, se registou um Marius Salaciensis (HAE 583).

A distribuição dos cognomes gregos também é significativa, limitando-se a Salacia e Tróia, característica da população de centros de feição urbana, com valor económico ou administrativo. Em Salacia ocorrem os seguintes: Corinthus, Himerus, Philon, Priamus, Teophilus, Zographus (Fig. 5).Em Tróia, o mesmo número: Antiocus, Callistratus, Chriseron (?), Copirus, Hypnus, Partenhopaeus (?). Assim, em 42 indivíduos seguramente identificados, 12 ostentam cognomina gregos, ou seja, 28,5\% do total, valor muito significativo. Não é necessário insistir na velha questão do verdadeiro significado étnico dos nomes gregos, pois estes podem, e aqui assim aconteceu com alguns, ocultar outras origens. Julgamos que este problema, resultante do grande espaço de mobilidade e de fusão cultural que era o Império, não pode ser considerado de forma global, exigindo análises regionais envolvendo os testemunhos arqueológicos das relações económicas envolvidas. Também neste aspecto a influência mediterrânica no litoral lusitano surge como preponderante.

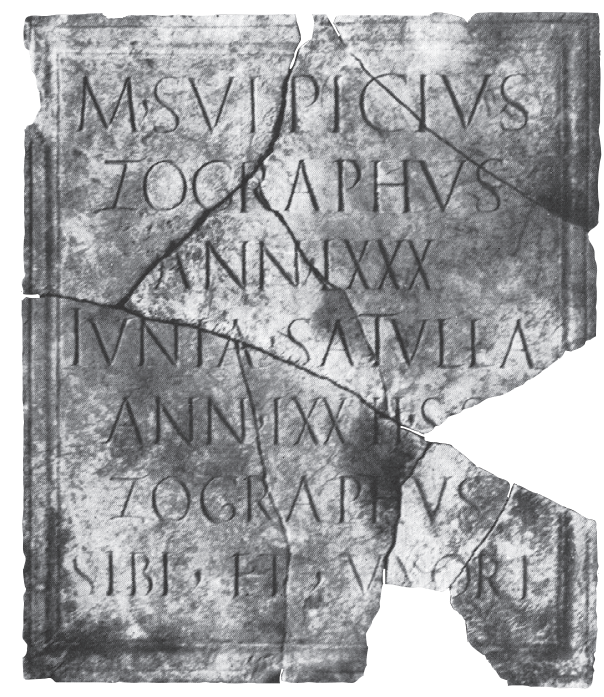

Fig. 5 - Placa funerária de Zographus, da necrópole do Senhor dos Mártires

${ }^{36}$ Abascal, p. 29 
O dinamismo dos libertos, por vezes simples reflexo de interesses que os manipulavam, afirmou-se também em Salacia, fazendo ascender alguns deles, admitindo que Philon e Himerus tinham ascendência servil (IRCP 186-187), a posições destacadas na sociedade local. Tal circunstância sugere, uma vez mais, a ascensão de elementos estranhos ao fundo populacional indígena, ao contrário do que parece ter sucedido em Olisipo, onde as magistraturas foram controladas por elementos oriundos da emigração livre e por indígenas romanizados $^{37}$, facto que permite considerar alguma subalternidade de Salacia, não obstante a inegável importância da cidade. O que se conhece do século I permite, com as cautelas necessárias, considerar uma prolongada tentativa de afirmação das elites locais, que não hesitaram em oferecer diversas vezes o exercício do duunvirato ao imperador ou a seus familiares, a exemplo do que sucedeu em Cádis e em Cartagena com o rei mauritano Juba ${ }^{38}$, o que só uma cidade prestigiada poderia intentar. Estas elites, pouco numerosas, deixaram à margem, parece, a população indígena, o que, aliado a uma aparente dependência de outros centros de poder, se revelou negativo a médio prazo. Lembramos que Flavia Rufina, flamínia provincial, como o foi também L. Cornelius Bocchus (CIL II 2979 = IRCP 189), e do município salaciense, era natural de Emerita (IRCP 183), pelo que a sua pertença a uma família romanizada não atenua a ausência deste grupo social entre os notáveis de Salacia.

Em resumo, tudo parece apontar para uma sociedade multi-étnica na qual os elementos indígenas, atlânticos, não conseguiram afirmar-se, fenómeno que talvez se possa explicar recuando no tempo e considerando a precoce integração da região nas estruturas económicas do mundo mediterrânico. O domínio romano, neste caso, não terá contribuído para criar um grupo de notáveis indígenas, lusitanos, suficientemente capaz de discutir com outros o poder local, como parece ter sido intentado no início do Império. Este mesmo predomínio mediterrânico revela-se claramente no campo religioso, não tanto pela ausência de cultos indígenas identificados no Baixo Sado, mas pela qualidade dos cultos orientais até agora reconhecidos em Salacia e em Tróia. A estes voltaremos oportunamente.

Problema muito discutido, e talvez ainda não definitivamente resolvido, é o do nome pré-romano de Alcácer do Sal. A fonte principal para o estudo da questão consiste nas moedas com legenda ibérica, moedas seguramente inspiradas por cunhagens do Círculo do Estreito e cujas legendas provocaram

${ }^{37}$ V. G. Mantas, “Os magistrados olisiponenses do período romano”, Turres Veteras, 7 (2004), Torres Vedras, Colibri, pp. 23-56.

${ }^{38}$ Avieno, Or.Mar., 270-283. 
várias leituras discordantes. Julgamos, como outros, que a leitura Ketovion nada tem a ver com Alcácer do Sal, cujo topónimo pré-romano seria Bevipum ou Bevipo $^{39}$, cujo sufixo -ipo obriga a situar entre os topónimos de filiação túrdula, pressupondo, como no caso de Olisipo, um anterior, por ora desconhecido. Talvez o referido sufixo se reflicta no hidrónimo Callipus, pelo qual Ptolomeu nomeia o Sado. Como dissemos, a legenda Ketovion corresponderá a Setúbal, representando a forma utilizada na época romana, Caetobrig $a$, uma celtização do topónimo, no qual não é possível ver qualquer referência à presença de cetárias, da mesma forma que Salacia não reflecte a presença das salinas do Baixo Sado ${ }^{40}$. Dir-se-á que uma povoação que cunha moeda no período pré-romano deve manter a sua importância, demonstrada pelos vestígios arqueológicos, o que ditou a identificação, mais ou menos romântica, de Caetobriga com as ruínas de Tróia. Na verdade, porém, não faltam povoações que decaíram completamente em termos administrativos, como poderá ser o caso de Caetobriga.

O topónimo romano de Alcácer do Sal também não está isento de problemas. Plínio denomina-a Urbs Imperatoria Salacia ${ }^{41}$, o que é posto em causa, quanto ao primeiro elemento por alguns investigadores. Recordamos a importância da cidade na época republicana, comprovada pela arqueologia, a qual explica, sem necessidade de complicadas teorias, a sua ligação aos pompeianos. Assim, o elemento Urbs pode considerar-se uma espécie de prenome, repetindo-se noutras grandes cidades marítimas da Hispânia, como Gades, Carthago Nova e Tarraco, e designando, em Roma, o centro antigo no interior do Muro de Sérvio. Reflecte, portanto, a proeminência jurídica, o valor e a antiguidade da cidade $^{42}$. A ausência do gentilício Iulia, numa cidade privilegiada nos inícios do Império pertencente à tribo Galéria, confirma, de alguma maneira, a atribuição do topónimo por Sexto Pompeio ${ }^{43}$, o que explica o termo Imperatoria, naturalmente relacionado com um imperator. Quanto ao termo Salacia,

${ }^{39}$ A. M. Faria, "Moeda e religião na Lusitânia", in J. C. Ribeiro (coord.), Religiões da Lusitânia. Loquuntur Saxa, Museu Nacional de Arqueologia, Lisboa, 2002, pp. 255-258.

${ }^{40}$ Outros topónimos hispânicos com sentido semelhante ao que se pretende atribuir a Salacia, como Carthago Spartaria, Salaria, Menlaria ou a ilha Scombraria aconselham, devido ao sufixo, a não considerar qualquer relação com salinas. A inclusão de nomes de divindades nos topónimos é vulgar na época republicana.

${ }^{41}$ Plínio, N.H., 4, 116-117.

${ }^{42}$ L. Homo, Rome impériale et l'urbanisme dans l'antiquité, Paris, Albin Michel, 1971², pp. 91-92; J. Peyras, "Statut des villes et territoire des cités: le mot "urbs" et ses derivés chez les arpenteurs romains", in M. Clavel-Lévêque / R. P.-Mallart (ed.), Cité et Territoire, Paris, Les Belles Lettres, 1995, pp. 33-66.

${ }^{43}$ M. Grant, From Imperium to Auctoritas, Cambridge, Cambrige University Press, $1969^{2}$, pp. 22-23, 408-410. 
não conseguimos, tal como André de Resende e Leite de Vasconcelos, interpretá-lo a não ser como uma alusão honorífica à deusa Salacia, esposa de Neptuno, divindade que corresponde à Anfitrite grega, especialmente relacionada, através do mito, com as águas exteriores e com o Extremo Ocidente ${ }^{44}$, invocação que parece lógica num centro urbano que era então o principal porto a ocidente de Cádis. No conjunto, o nome oficial da cidade corresponde a outros, típicos do período republicano, anteriores à introdução de topónimos de tipo dinástico, como Iulia Myrtilis, Pax Iulia, Liberalitas Iulia Ebora e Felicitas Iulia Olisipo, reflectindo estes a ideologia do primeiro imperador ${ }^{45}$. Teremos, assim, uma primeira promoção pompeiana de Salacia, talvez congelada por razões políticas quase até finais do século I a.C., quando Augusto a recupera para o grupo de cidades privilegiadas da Lusitânia, ainda que se note a raridade do gentilício Iulius na epigrafia local, em evidente contraste com a sua copiosa presença nas cidades atrás referidas. Seria de grande interesse estudar os materiais arqueológicos atribuíveis aos primeiros anos do Império, no sentido de detectar quaisquer alterações que possam sugerir situações de abrandamento económico coincidentes com situações de enfraquecimento político.

O que se conhece do urbanismo romano de Salacia é ainda relativamente pouco, podendo reconhecer-se a posição típica de um oppidum de fácil defesa, controlando um porto fluvial, ao qual sucedeu a cidade romana. Foi possível localizar o fórum, muito destruído (Fig. 6), no ponto mais elevado da urbe, cujo casario descia pela encosta oriental, segundo uma estrutura pouco regular, até ao porto, ao longo da margem direita do rio $^{46}$. Aqui se situariam cais e armazéns e, nas cercanias da área urbana, zonas artesanais, com numerosos fornos de ânforas, e necrópoles ${ }^{47}$. Considerando que os navios de alto bordo podiam atingir Salacia, é possível que embarcações fluviais procedessem ao transbordo directo para esses navios dos produtos embarcados nos estabelecimentos ao longo do rio. Esta mesma circunstância, considerando a dispersão das unidades de produção de preparados piscícolas, pode ter contribuído gradualmente para transferir grande parte do movimento marítimo para o estuário do Sado, evitando a subida do rio até Salacia.

Na época de Cláudio, na qual é possível situar o apogeu dos Bocchi, a cidade conheceu um surto de desenvolvimento, a relacionar com o patrocínio de

${ }^{44}$ R.Martin, Dicionário cultural da mitologia greco-romana, Lisboa, Publicações Dom Quixote, 1995,pp. 40-41; RE, I,A2, 1960², col. 1818-1822; X (Supp.), 1965², col. 2517-2519.

${ }^{45}$ R. Étienne, Le siècle d'Auguste, Paris, Armand Colin, 1970, pp. 90-100.

46 J. L. Faria, Alcácer do Sal ao tempo dos Romanos, Lisboa, Colibri, 2002, p. 66.

${ }^{47}$ V. G. Mantas, "As cidades marítimas da Lusitânia", in J.-G. Gorges (ed.), Les Villes de Lusitanie Romaine, Paris, 1990, Éditions du CNRS, pp. 175-177; J.L. Faria, pp. 57-62, 115. 


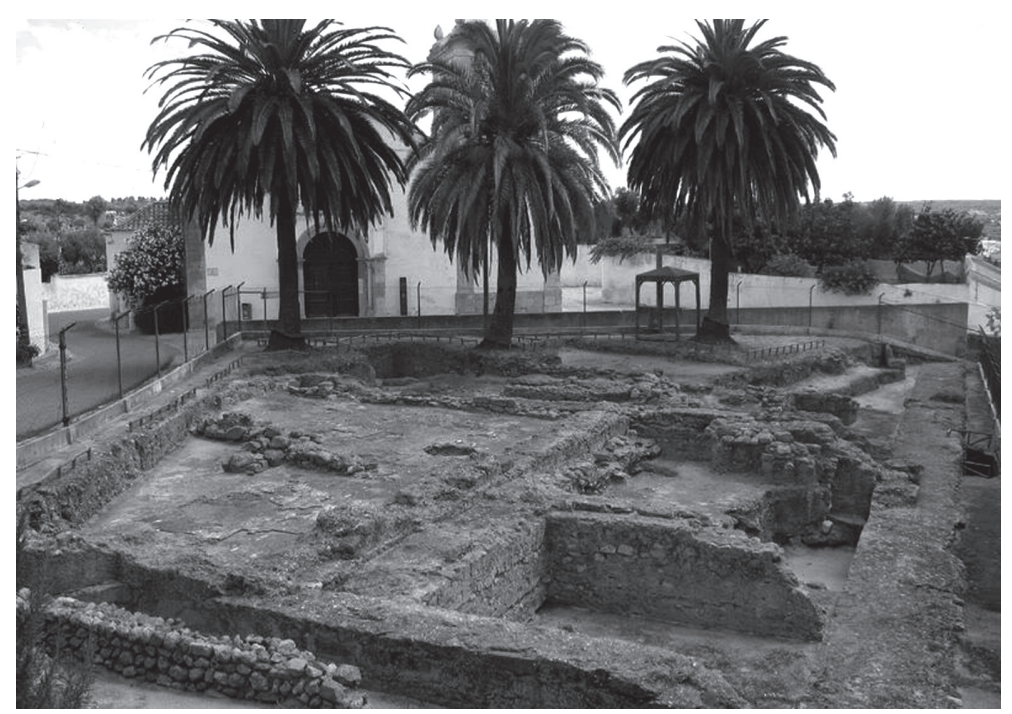

Fig. 6 - Ruínas do forum de Salacia, junto à igreja de Nossa Senhora do Castelo

L. Cornelius Bocchus e ao impacte, na economia local, das operações logísticas desenvolvidas na Lusitânia por ocasião das operações militares de anexação da Mauritânia, no quadro da renovada política atlântica do imperador. O retrato de Cláudio, achado em Alcácer do Sal, invoca um tempo em que o interesse pelas províncias ocidentais e pelo seu desenvolvimento representou uma notável realidade política e administrativa ${ }^{48}$, entre a acção de Augusto e a de Vespasiano, que não pode ser ignorada ou minimizada ${ }^{49}$.

É talvez neste cenário que devemos situar a criação ou, pelo menos, o desenvolvimento do vicus de Tróia, atribuído por Jorge de Alarcão aos Bocchi. Nessa época o sítio devia ter características quase insulare ${ }^{50}$, o que não deixava de suscitar alguns problemas de ordem prática, como o do abastecimento de combustíveis, já que não havia dificuldades com a água doce ${ }^{51}$. Também é certo

${ }^{48}$ L. R. Gonçalves, Escultura romana em Portugal: uma arte do quotidiano, Mérida, Museo Nacional de Arte Romano, 2007, pp. 82-84; D. Nony, "Claude et les Espagnols sur un passage de l'Apocoloquintose", Mélanges de la Casa de Veláquez, 4 (1968), pp. 51-71.

49 J. M. Abascal / U. Espinosa, La ciudad hispano-romana. Privilegio y poder, Logronho, Colegio de Aparejadores y Arquitectos Técnicos, 1989, pp. 68-70.

${ }^{50}$ R. Étienne et alii, Un grand complexe industriel à Tróia (Portugal), Paris, De Boccard, 1994, pp. 16-18.

${ }^{51}$ J. Alarcão, Roman Portugal, I, 2, Warminster, Phillips \& Arris, 1988, pp. 128-132; A. C. Quintela et alii, Aproveitamentos hidráulicos romanos a sul do Tejo, Lisboa, Ministério do Planeamento e Administração do Território, 1986, pp. 128-129. 
que Tróia apresentava vantagens, uma das quais era a excelente localização no estuário, constituindo um porto de abrigo natural muito conveniente, protegido da nortada pela massa da Serra da Arrábida (Fig. 7).

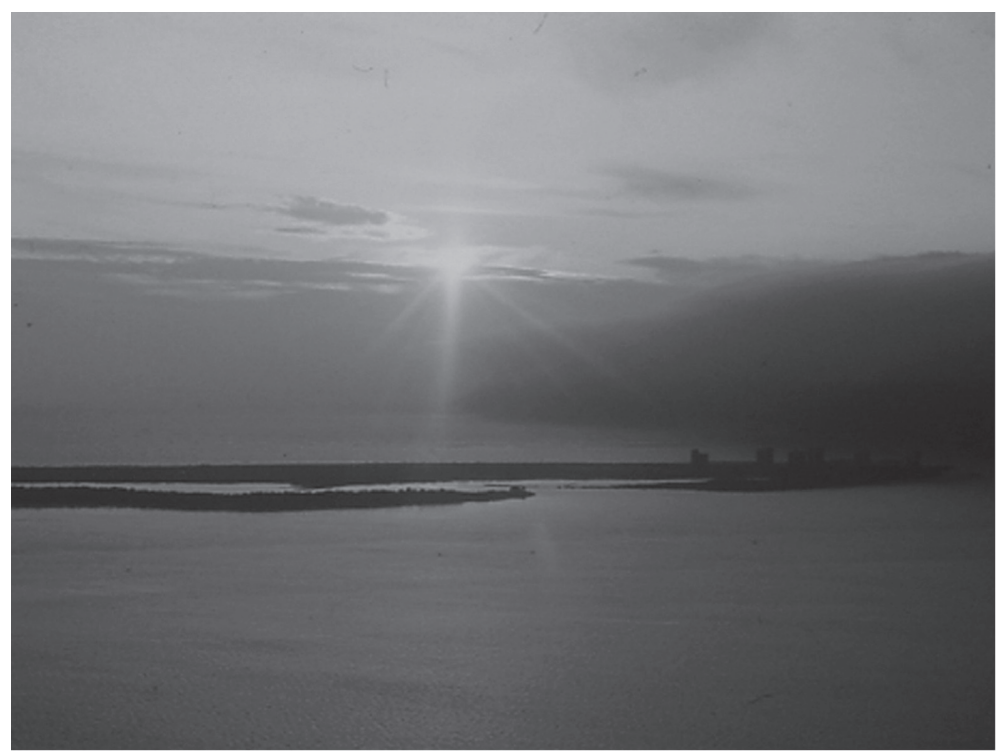

Fig. 7 - A ponta de Tróia, a foz do Sado e a Arrábida, em fim de tarde

A localização de Tróia, muito perto da barra do rio, permitia uma fácil concentração de preparados piscícolas produzidos nos numerosos estabelecimentos de salga dispersos na região, dispensando os grandes navios de procurar Salacia e simplificando o tráfico fluvial (caudicariae, scaphae) entre os locais de produção e os pontos de embarque definitivo. Podemos recriar o que foi a actividade no Sado durante a época romana, em parte relacionada com villae como as da Senhora da Graça e da Comenda (Fig. 8), cuja economia assentava basicamente nas conservas de peixe. Como as unidades fabris necessitavam de contentores em grande número, quando os não produziam localmente, o transporte de ânforas ocupou decerto os meios disponíveis, durante uma parte do ano, de acordo com um calendário ainda pouco estudado.

A exploração das ruínas de Tróia, tantas vezes começada e interrompida, levantou sempre problemas, ao que se juntou, nos últimos anos, a questão do aproveitamento turístico da zona, permanecendo muitas dúvidas sobre o futuro da estação arqueológica e da sua envolvente terrestre e fluvial. Já se sugeriu 


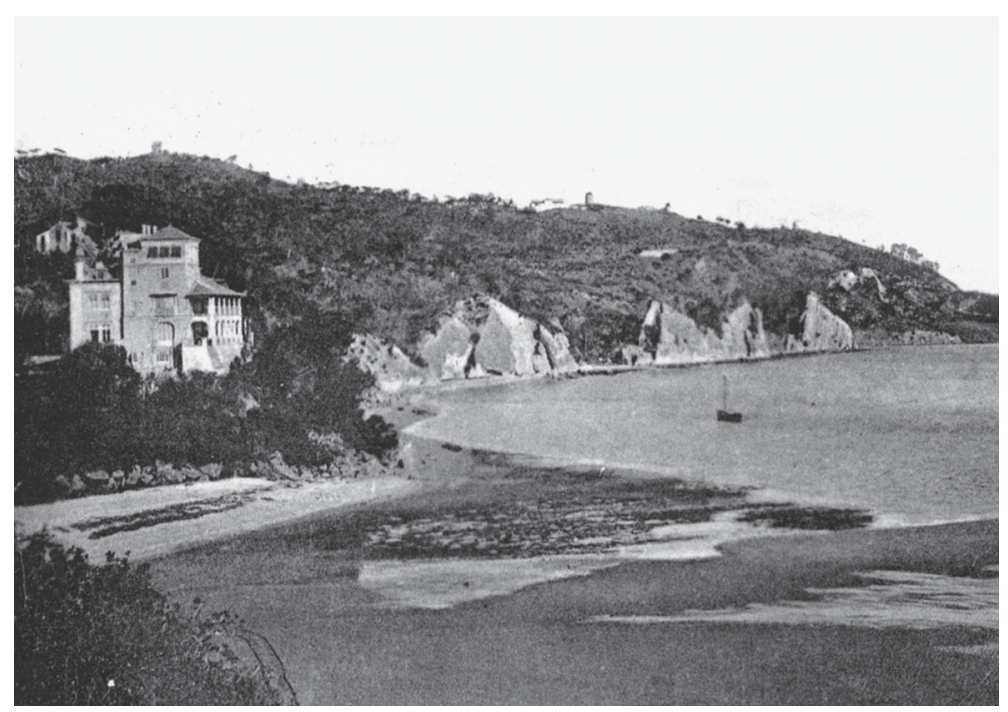

Fig. 8 - O sítio da villa da Comenda num postal de cerca de 1920

a possibilidade de Tróia constituir um aglomerado de villae $e^{52}$, proposta difícil de compreender, não só pela extensão inusitada e características das ruínas, onde se identificaram arruamentos, como também pela variedade de gentilícios proporcionada pela epigrafia da zona escavada, que conta com oito diferentes. Continuamos, como sempre fizemos, a considerar as ruínas como vestígios de um vicus industrial, correspondente a um dos maiores centros de produção de preparados piscícolas do mundo romano. A riqueza ictiológica do Atlântico, posta em relevo na Antiguidade quando comparada com a modéstia do Mare Nostrum $^{53}$, surge, neste caso exemplar, ao serviço de redes económicas e de práticas alimentares perfeitamente mediterrânicas. As ruínas, incluindo os edifícios escavados desde o século XVIII e que hoje se encontram sob as dunas, ocupam uma extensa área ao longo do rio, prolongando-se as cetárias, segundo testemunhos escritos, por cerca de quatro quilómetros ${ }^{54}$.

52 Étienne et alii, pp. 161-167.

${ }^{53}$ Estrabão, 3, 1, 8; Plínio, N.H., 31, 43, 94.

${ }^{54}$ F. Castelo-Branco, “Aspectos e problemas arqueológicos de Tróia de Setúbal”, Ocidente, 65, 304 (1963), pp. 79-96; J. Alarcão, “A produção e a circulação dos produtos”, in J. Alarcão (coord.), Nova História de Portugal, I, Lisboa, Editorial Presença, 1990, pp. 428-429. 
Os vestígios das práticas funerárias observadas em Tróia mostram a coexistência de ritos de notável diversidade, com influências marcantes de origem oriental e norte-africana. A actividade industrial desenvolvida em Tróia reflecte-se, por exemplo, na anforeta representada numa placa funerária, datada da segunda metade do século I, sugerindo possíveis contactos com a Itália (IRCP 223). Num núcleo sepulcral, estabelecido junto a uma das zonas fabris, situa-se um columbário, que cremos ter pertencido a uma corporação profissional, cuja existência em Tróia é perfeitamente possível. O vicus parece ter conhecido um processo de decadência progressiva, a partir do século IV, sobrevivendo até finais do século seguinte, quando as brutais perturbações no comércio romano e fenómenos de transgressão marinha terão ditado o seu abandono progressivo ${ }^{55}$.

Ao contrário de Tróia, a informação sobre Caetobriga é muito recente, remontando a meados do século passado. Caetobriga vivia da indústria da pesca, contando com numerosos agrupamentos de cetárias descobertos em trabalhos diversos desde os anos 80 do século XX. O oppidum da Idade do Ferro situava-se na colina de $\mathrm{S}$. Sebastião, onde não faltam materiais cerâmicos fenício-púnicos ${ }^{56}$. Caetobriga ocorre como mansio no Itinerário de Antonino $(I t .417,1)$, voltando a surgir na tardia lista de estações do Anónimo de Ravena (Rav.IV,43), circunstância que comprova a sua importância viária, a qual deve ter constituído, também, um elemento relevante na sua vida económica. Apesar de tudo, Caetobriga não parece ter sido mais do que uma aglomeração secundária dependente de Salacia. A não identificação de restos monumentais de qualquer tipo, até ao presente, mais do que a falta de testemunhos epigráficos, aponta nesse sentido ${ }^{57}$. A actividade portuária foi certamente importante, pois o estuário funcionou como um complexo portuário, enquadrando-se bem no cenário de povoação industrial. Trata-se, portanto, de um oppidum romanizado, com suficiente importância para ser referido por Ptolomeu, apesar de não se lhe conhecer qualquer estatuto privilegiado. A povoação teve flutuações na sua actividade, por enquanto difíceis de explicar, talvez relacionadas com o sucesso de Tróia, pois quando esta começa a decair voltamos a encontrar, de acordo com os dados arqueológicos, uma retoma nas actividades fabris em Caetobriga,

${ }^{55}$ C. T. Silva / M. G. Cabrita, "O problema da destruição da povoação romana de Tróia de Setúbal”, Revista de Guimarães, 76 (1967), pp. 147-156. A submersão de sítios costeiros pode dever-se à subida do nível médio das águas do mar ou a fenómenos tectónicos. Sítios como Baelo, junto ao Estreito de Gibraltar, e outros, nomeadamente ao longo do litoral algarvio, ilustram perfeitamente tais alterações geomorfológicas.

${ }^{56}$ J. Soares / C. T. Silva, "Ocupação pré-romana de Setúbal”, Trabalhos de Arqueologia, 3 (1986), pp. 87-101.

${ }^{57}$ Silva / Soares, pp. 178-194. 
com uma nítida recuperação nos séculos IV e $\mathrm{V}^{58}$. O achado de ânforas Dressel 23 em Caetobriga mostra que as relações com a Bética sobreviveram à chamada crise do século III, representando um indicador muito interessante considerando a presença deste contentor, que substituiu a famosa Dressel 20, na faixa atlântica ocidental e, em quantidades significativas, na Germânia ${ }^{59}$. A montante, Alcácer do Sal manteve alguma relevância na Antiguidade Tardia, como mostram os vidros bizantinos encontrados no Castelo, mantendo as suas funções flúvio-marítimas até à Reconquista, funções que serão continuadas por Setúbal, agora num contexto predominantemente atlântico ${ }^{60}$.

Uma breve referência ao universo religioso de Salacia e de Tróia confirma-lhes as características de centros portuários mediterrânicos. É claro que a falta de achados que ilustrem as crenças religiosas professadas pelas camadas indígenas mais humildes, que nesta região, aliás, parecem profundamente aculturadas desde que sofreram a influência fenício-púnica, sugere alguma cautela nas generalizações, mas o que chegou até nós não deixa dúvidas quanto à presença de um forte horizonte religioso orientalizante. Em Alcácer, embora o local do achado permaneça obscuro, uma inscrição a Ísis afirma a ligação ao Oriente (CIL II $33=I R C P$ 182), através da versão helenística desta divindade egípcia, mas invoca também a deusa como protectora das mulheres e da navegação ${ }^{61}$. O Oriente helenístico reflecte-se igualmente, e a um nível bastante significativo, pois envolve manifestações perto das crendices populares, na defixio achada nas escavações no Convento de Aracoeli, não muito longe do forum, instando a Grande Deusa a castigar um larápio ${ }^{62}$, ou nas estatuetas de terracota de Átis, achadas recentemente.

Tróia facultou um relevo representando o banquete de Mitra e de Hélio, nas ruínas do que pode ter sido um Mithraeum, raríssimo na Hispania ${ }^{63}$.

${ }^{58}$ Soares / Silva, pp. 155-160; Silva / Soares, pp. 184-194.

${ }^{59}$ J. R. Rodríguez, "Transformaciones en la exportación del aceite bético a mediados del siglo III d.C.”, in J. M. Blázquez / J. R. Rodríguez (coord.), Producción y Comercio del Aceite en la Antigüedad, II, Madrid, Universidad Complutense, 1983, p. 129.

${ }^{60} \mathrm{M}$. L. Blot, Os portos na origem dos centros urbanos, Lisboa, Instituto Português de Arqueologia, 2003,pp. 260-269.

${ }^{61}$ Apuleio, Met., 11, 15-17; J. Alvar, "Cultos orientais e mistéricos na província da Lusitânia", in J. C. Ribeiro (coord.) Religiões da Lusitânia. Loquuntur Saxa, Lisboa, Museu Nacional de Arqueologia, 2002, pp. 205-210.

${ }^{62}$ J. d'Encarnação / J. L. Faria, "O santuário romano e a Defixitio de Alcácer do Sal", in J. C. Ribeiro (coord.), Religiões da Lusitânia. Loquuntur Saxa, Museu Nacional de Arqueologia, Lisboa, 2002, pp. 259-263.

${ }^{63}$ R. Turcan, Mithra et le Mithriacisme, Paris, Presses Universitaires de France, 1981, pp. 31-34; Alarcão, Domínio, pp. 173-174. 
Também em Tróia, uma construção relativamente cuidada, com três naves e classificada como edifício de culto paleocristão, poderá ter sido, de início, uma sinagoga. Os contactos comerciais com a Palestina e com as comunidades judaicas norte-africanas foram mais vulgares do que as fontes escritas sugerem e devem ter-se ampliado no Baixo Império. Duas lucernas achadas em Tróia, uma com a representação dos exploradores de Canã e outra com a Menorah figurada no disco (Fig. 9), reforçam a nossa hipótese ${ }^{64}$, sem esquecer a abundante antroponímia grega entre os membros da Diaspora ${ }^{65}$, antroponímia bem representada em Salacia e em Tróia. As únicas presenças paleocristãs resumem-se a algumas lucernas e ao edifício tardo-romano que referimos, assim como, talvez, à necrópole com sepulturas tipo mensae, que lhe fica próxima, denotando, mais uma vez, a influência africana em

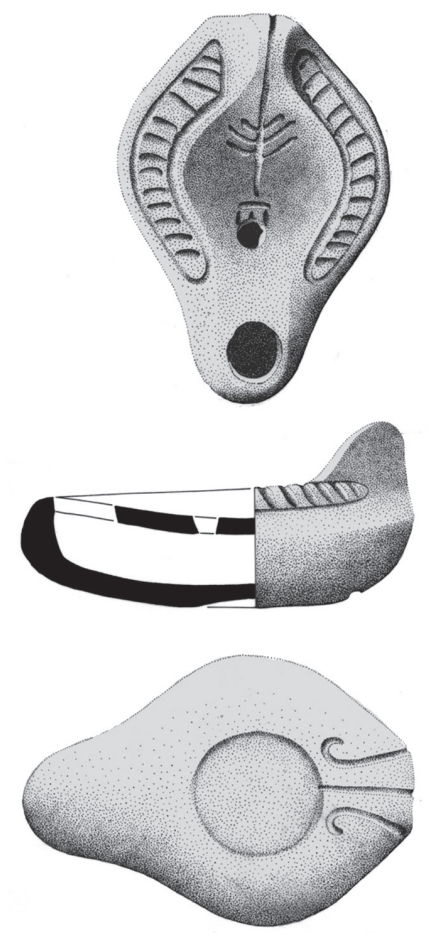

Fig. 9 - Lucerna de Tróia com figura da Menorah do Templo de Jerusalém

${ }^{64}$ Estas lucernas encontram-se, respectivamente, no Museu Regional de Évora e no Museu de Arqueologia de Setúbal. A primeira é seguramente norte-africana; a segunda pode ser cópia local de uma peça produzida na região de Cartago.

${ }^{65}$ P. Lévêque, Le monde hellénistique, Paris, Armand Colin, 19924, pp. 48-53. 
Tróia. De qualquer forma, as relações comerciais dos portos sadinos devem ter contribuído para cedo introduzir o Cristianismo na região, como sucedeu noutros centros portuários, como Ossonoba (Faro) e Olisipo, sem que naqueles se tenha constituído uma sede episcopal. Poderemos daqui inferir um processo de declínio de Salacia durante a Antiguidade Tardia?

A história dos portos do Sado na época romana, muito rapidamente evocada, mostra-nos, de forma inquestionável, o produto de um permanente influxo cultural mediterrânico, próprio do complexo processo a que, à falta de melhor, chamamos Romanização ${ }^{66}$. Uma das primeiras conclusões a extrair é a do papel fundamental dos portos neste processo, assim como a verificação de amplos movimentos culturais, de forma alguma limitados aos valores do mundo grecoromano, que lhes serve, afinal, de veículo difusor. Também os altos e baixos de um mundo enorme e complexo se fizeram sentir neste Extremo Ocidente onde se via o Sol mergulhar no Oceano, até que a história continuou, com novos figurantes, num cenário civilizacional que era, para não dizer mais, diferente, muito diferente.

Não deixa de ser interessante concluir que a nova realidade, na qual Setúbal assume posição capital como porto atlântico, repete o que já tinha existido, desenvolvendo uma economia atlântica baseada em produtos mediterrânicos, frutos, vinhos, sal, conservas (Fig. 10). Não se repetia a antiga rota britânica quando, na Idade Média, os navios transportavam para os portos ingleses nos finais do Outono, os produtos sadinos ${ }^{67}$, entre os quais as laranjas oferecidas pelo Natal como prenda preciosa? A história talvez não se repita, mas existem factores que a condicionam, para o bem e para o mal, ao longo dos tempos. Num momento em que os efeitos perversos da globalização, anacronicamente comparada com o Império Romano, se fazem sentir no Baixo Sado, recordamos o que alguém escreveu sobre Setúbal por altura do já longínquo ano de 1924: A primeira indústria de Setúbal foram as salinas. Hoje a sua grande riqueza são as fábricas de conserva de peixe que é exportada para todo o mundo em enormes quantidades no valor de alguns milhares de contos [...]. Tem fábricas de cortiça e de vinho moscatel muito afamado. As laranjas da região gozam de grande fama, tanto em verde como em doce ${ }^{68}$.

${ }^{66}$ A. B. Molina, Orbe romano e imperio global. La romanización desde Augusto a Caracalla, Santiago de Chile, Editora Universitária, 2007, pp. 65-68.

${ }^{67}$ Cunliffe, pp. 104-105, 538-541.

${ }^{68}$ C. de Ornelas, Guia do viajante em Portugal, Lisboa, Gazeta dos Caminhos de Ferro, $1924^{5}$, p. 97. 

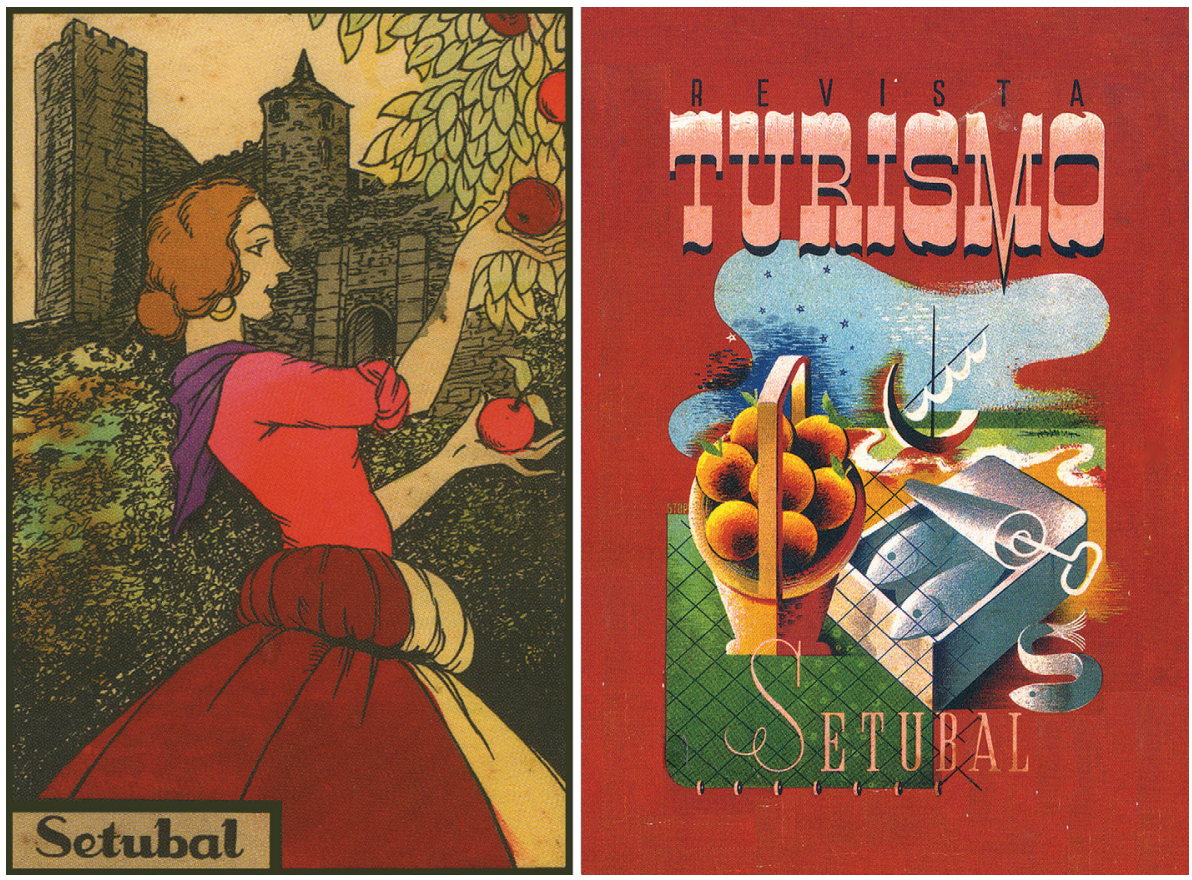

Fig. 10 - Cartaz e revista publicitando produtos da região setubalense

Recebido em/Submitted on: 03/01/2011 Aceite em/Approved on: 07/02/2011 
